University of Chicago Law School

Chicago Unbound

Public Law and Legal Theory Working Papers

Working Papers

2015

\title{
Empathy and Masculinity in Harper Lee's To Kill A Mockingbird
}

Richard H. McAdams

Follow this and additional works at: https://chicagounbound.uchicago.edu/public_law_and_legal_theory

Part of the Law Commons

Chicago Unbound includes both works in progress and final versions of articles. Please be aware that a more recent version of this article may be available on Chicago Unbound, SSRN or elsewhere.

\section{Recommended Citation}

Richard H. McAdams, "Empathy and Masculinity in Harper Lee's To Kill A Mockingbird" (University of Chicago Public Law \& Legal Theory Working Paper No. 539, 2015).

This Working Paper is brought to you for free and open access by the Working Papers at Chicago Unbound. It has been accepted for inclusion in Public Law and Legal Theory Working Papers by an authorized administrator of Chicago Unbound. For more information, please contact unbound@law.uchicago.edu. 


\section{CHICAGO}

PUblic LAW AND Legal TheORY WORKING PAPER No. 539

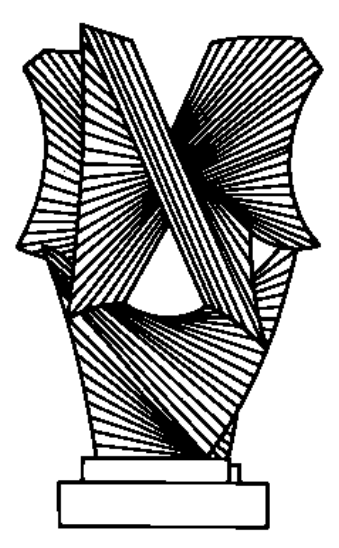

EMPATHY AND MASCULINITY IN HARPER LEE'S TO KILL A MOCKINGBIRD (CH. 13 IN AMERICAN GUY: MASCULINITY IN AMERICAN LAW AND LITERATURE EDITED BY SAUL LEVMORE AND MARTHA C. NUSSBAUM)

Richard H. McAdams

\section{THE LAW SCHOOL THE UNIVERSITY OF CHICAGO}

August 2015

This paper can be downloaded without charge at the Public Law and Legal Theory Working Paper Series: http://www.law.uchicago.edu/academics/publiclaw/index.html and The Social Science Research Network Electronic Paper Collection. 


\section{American Guy}

MASCULINITY IN AMERICAN LAW AND LITERATURE

Edited by Saul Levmore

and Martha C. Nussbaum

2 
I know now what he was trying to do, but Atticus was only a man. It takes a woman to do that kind of work.

\section{3}

Empathy and Masculinity in Harper Lee's To Kill a Mockingbird Richard H.McAdams*

AS DIFFICULT AS it is to say anything new about Harper Lee's To Kill a Mockingbird, I will press my luck and offer two claims. My main thesis is that Mockingbird illustrates a troubled, two-sided relationship between lawyering and empathy. ${ }^{2}$ Discussions of empathy conventionally address its pro-social aspect, the tendency for empathetic understanding to produce compassionate or altruistic behavior. Less frequently observed is the strategic value of empathy, the fact that a competitor who understands the thoughts and feelings of others is better able to anticipate an opponent's next move and stay one step ahead. Atticus Finch demonstrates both aspects of empathy: his ability to imagine the world from the perspective of others makes him a more compassionate and helpful father and neighbor, but also a more effective lawyer, better able to cross-examine adverse witnesses and to make arguments that (might) appeal to jurors. Atticus understands better than anyone else in Maycomb the tragic predicament of Mayella Ewell, but he uses his empathy to harm her, that is, to help his client Tom Robinson by exposing her as a liar. The irony is that the empathetic insight that makes Atticus the best person to cross-examine Mayella also makes him (among all those who believe she is lying) feel the most compassion for her. But the role of zealous advocate leaves limited room for showing compassion to one's adversary.

My second thesis connects empathy to the theme of masculinity. The novel pointedly offers a new version of white manhood in the Jim Crow South. The conventional white southern male of the r93os romanticized the Lost Cause of the Confederacy and adhered to a strict code of chivalry that required the use of violence to assuage insults to honor, particularly the honor of white southern women. According to 
this chivalric ideology, the greatest threat to white womanhood was black male predation, and the manly response was the lynching, not only of alleged black rapists but of other black men whose behavior seemed to question white supremacy. The novel offers Atticus as a male hero who rejects the white supremacist assumptions of lynching. Less obvious are the tools the novel uses to draw our attention to the concept of manhood and to invert its standard meaning. Atticus' courage is nonviolent, which the novel contrasts with cowardly violence; Atticus fights for a lost cause that is not the Confederacy, but its victim; and Atticus acts valiantly by protecting an innocent black man from the accusation of a white woman. Southern chivalry is turned on its head.

The connection between these claims is that Atticus' heightened sense of empathy is one of the key ways in which he systematically violates period expectations for manliness. I begin with the general theme of manhood and then turn to the specific issue of empathy.

\section{DESTABILIZING AND RECONSTRUCTING}

\section{JIM CROW MASCULINITY}

On a conventional view, manliness is a higher-order value such as strength. Atticus Finch is masculine in a straightforward way because he shows strength by confronting a lynch mob and by defending Tom Robinson in court, despite the disapproval of his community. Yet in other obvious ways Atticus is unmanly because he lacks so many of the markers of manliness standard to his time.

One should distinguish the inward quality of manliness, whatever it precisely is (e.g., strength, courage), from the masculine markers commonly taken as evidence of manliness. Upper body strength and emotional control are external markers; they are understood to correlate with manliness, but they are neither strictly necessary nor sufficient for it. The markers are important, however, because they are more tangible than the actual thing and are part of the everyday struggle to demonstrate manliness. As Michael Warner explains, ${ }^{3}$ the default setting for manliness is failure. The presumption being to the contrary, men have to prove that they are manly. And the value of a single demonstration decays over time, so that one must prove that one is still manly. Moreover, manliness is always contested; there are few avenues of definitive proof. And those that do exist-success in combat or life-and-death struggles with nature-are scarce for a modern man, especially if one cannot count on his past success to prove his manliness for the rest of his life. Given scarce opportunities, much of the social practice of manliness is focused on the display of masculine markers, which are sometimes confused for strength or whatever the ultimate characteristic that manliness actually is. 
However slippery the concept, we can identify some obvious markers of masculinity for a 1930 s white southerner. The striking fact is that Atticus lacks so many. He doesn't hunt. He doesn't fish, drink, or smoke. Atticus doesn't play poker or football (pp. 102-3). He comes directly home after work, sits in the living room and reads; we never hear of him bonding with other men. Atticus is gentle in ways that might be mistaken for weakness, particularly his avoidance of physical violence. He doesn't corporally punish his children (pp. 63, 100). He refuses to respond when Bob Ewell spits in his face (p. 248). Atticus is affectionate. Scout sits in his lap when he reads, which is presumably how she learned to read at such a young age that she can't remember not reading. And Scout says that Atticus and his brother Jack "were the only two men she ever saw kiss each other" (p. 89). When members of Maycomb's black community leave him presents of food after the trial, "Atticus' eyes filled with tears" (p. 244).

The connection to manhood is explicit. When Miss Maudie's house is on fire, Scout and Jem observe that Atticus doesn't go up on a roof like other men because he was "too old" and "might break his neck" (p. 80). Due to his age, "nearly fifty," Scout describes Atticus as "feeble" and says that she and Jem felt that his being old, due to the fact that he started his family late, "reflected upon his abilities and his manliness" (p. 102). They feel they had nothing to say when other children told stories about their fathers because Atticus "didn't do anything," by which Scout means that he did not have a manly occupation: "Atticus did not drive a dump-truck for the county, he was not the sheriff, he did not farm, work in a garage, or do anything that could possibly arouse the admiration of anyone" (p. 102). "Besides that, he wore glasses" (p. 102). Atticus' glasses are a sign that he reads and writes for a living. And, of course, as a trial lawyer, he speaks for a living. Where "real men" are men of action, who quietly do things, Articus is merely a man of words, apparently not much of a man at all.*

Of course, we don't have to wait for Atticus to stand up to a lynch mob in order for him to arouse the admiration of his children. In their eyes, he first proves himself with the incident of the rabid dog. When Calpurnia calls Atticus at work to warn him of a "mad" dog on the street, Atticus immediately drives over with the sheriff Heck Tate. Tate bears obvious masculine markers. He is a sheriff and that day he "wore boots with shiny metal eye-holes, boot pants and lumber jacket. His belt had a row of bullets sticking in it" (pp. 107-8). But when the time comes to shoot the dog, Tate asks Atticus to do the job. At the distance required, the shot is difficult and, though Scout and Jem have never seen Atticus fire a gun, it turns out that, "in his time," he "was the deadest shot in Maycomb County" (p. I12). His children, especially Jem, are overwhelmed. The rabid dog story foreshadows the possibility that Atticus has hidden strength, that one can be manly even if one lacks the outward markers of manliness. 
The novel draws further attention to these markers with their unexpected presence in the unlady-like Scout. Scout disdains dresses in favor of overalls (p. 92). She plays with boys (Jem and Dill), cusses (p. 90), enjoys her air rifle Christmas present (p. 91), and likes to fight (passim!). On each occasion where she has the urge to fight, her intended or actual target is a boy: Jem, Dill, her classmates Walter and Cecil, and her cousin Francis. And Scout fights for real. When Francis baits her about Atticus, she "split[s] [her] knuckle to the bone on his front teeth" (p. 96). Even the nickname Scout suggests a military position, very much unlike her unused given name, Jean Louise. No wonder that Aunt Alexandra moves in with her brother Atticus so that she can provide a "feminine influence" for Scout (p. 145). Early in the novel, Jem frequently insults his sister for "acting like a girl," but later he seerns to endorse Aunt Alexandra's plan, saying to Scout: "She's trying to make you a lady. Can't you take up sewin' or somethin'?" to which the eight-year-old replies "Hell no" (p. 257).

The novel also pointedly refers to the (literal) construction of gender in the story of the snow person that Jem builds. Lacking enough snow for an ordinary snowman, he starts with a base of mud, to which he adds a thin coating of snow. Scout and Jem observe that the addition quickly changes the apparent race of the creation from black to white (p. 75). Jem then shapes the snow creature to look like the neighbor, Mr. Avery. The appearance is striking and unflatrering. When Atticus arrives, he is amused but comments that it is "a near libel." "We've got to disguise it" (p. 76). Atticus suggests that Jem give the snowman a broom and apron-to make it a snowwoman-but Jem instead uses Miss Maudie's sunhat and hedge clippers. Miss Maudie is tickled at the transformation, but apparently finds it to be less than completely successful. During her conversation with Atticus, Scout comically mishears Miss Maudie refer to the snow creature as "an absolute morphodite" (p. 77), a term Scout repeats on two later occasions (pp. 84, 156).

There is nothing accidental here about the references to a hermaphrodite, the unmanliness of Atticus, and the masculine traits of Scout. By these details, the novel unsettles expectations about the markers and meanings of manliness, so it can reconstruct them into a new type of white southern hero. As I count them, that alternative construction involves three inversions of the Jim Crow code of white chivalry.

First, southern white males conventionally embraced violence more than their northern and western white counterparts. This was obviously the case in the Jim Crow South, as white men used violence to enforce a white supremacist social order. ${ }^{6}$ But even long after the end of Jim Crow, social science finds that southern white men are more inclined than nonsouthern white men to use violence in response to 
verbal insults and that southern institutions are more likely to excuse and forgive honor violence than are nonsouthern institutions. One wins an argument with fists, not words.?

In the novel, however, we see violent responses to insults occur, not by the male hero but in two other characters: Scout and Bob Ewell. Scout's violence is obviously unmanly because it is childish. In the story, growing up involves Scout's learning to control her violent impulses. Bob's most violent outburst occurs when he tries to murder Jem and Scout, in retaliation for being humiliated (along with Mayella Ewell) by Atticus' cross-examination during the trial of Tom Robinson. But this attempted "honor" killing of children is obviously a supreme act of cowardice. There is also, of course, the attempted violence of the lynch mob that go to the jail, seeking to kill Tom, to defend the honor of Mayella. Yet that mob, which Atticus calls a "gang of wild animals" (p. 179), is also discredited in various ways by the story, including the apparent fact of Tom's innocence and the fact that it could be so easily shamed by Scout.

By contrast, Atticus refuses to respond to a most outrageous insult when Bob "cursed him, spat on him, and threatened to kill him" (p. 248). Bob's tobacco-lader spittle landed on Atticus' face. This is exactly the kind of provocatory act that would, in the period, have easily led to lethal violence (and was probably intended to so do). Because Atticus uses words as a weapon, we might not have expected him to respond with violence in any event. But he also holds his tongue against Bob, expressing none of the outrage he must have felt. Out of context, his restraint might seem cowardly. But by the time of the spitting incident, Atticus has already shown extraordinary courage by defending Tom against the law and the mob, both without the use of physical violence. Thus, his restraint demonstrates enormous self-control. And we believe him when he later tells Jem that he wanted to let Bob have the last word, and to feel he had gained back his honor, so as to save Mayella or some other Ewell child from "one extra beating" (p. 249). Thus, again, Atticus is manly for sacrificing for the sake of someone weaker than himself.

Which brings us to the second point: Jim Crow masculinity embraced a southern code of chivalry that contemplated white men protecting white women from black predation. This was the ideology of lynching. As Arthur Raper explains in his 1933 study, "Regardless of the cause of a particular lynching, there were always those who defended it by the insistence that unless Negroes were lynched, no white woman would be safe." In 1930, Jessie Daniel Ames, a white woman, founded the Association of Southern Women for the Prevention of Lynching precisely because she thought it vital that the supposed beneficiaries of lynching attack this central chivalric justification. ${ }^{\circ}$ But Ames was the exception. In the novel, Scout hears white women express this sexual fear of black men and the need for protection. Outside 
the courthouse, Scout overhears a white woman say "[I]t's time somebody taught 'em a lesson, they were getting' way above themselves, an' the next thing they think they can do is marry us" (p. 283). At a meeting of her aunt's missionary circle, another white woman expresses the fear that "there's no lady safe in her bed these nights" (p. 265).

Mayella makes a direct appeal to chivalry at the end of her testimony against Tom. Atticus has frustrated her by exposing various weaknesses and inconsistencies in her account, so she stops talking about the facts and challenges the masculinity of the white male jurors:

"I got somethin' to say an' then I ain't gonna say no more. That nigger yonder took advantage of me an' if you fine fancy gentlemen don't wanta do nothin' about it then you're all yellow stinkin' cowards, stinkin' cowards, the lot of you. Your fancy airs don't come to nothin'-your ma'amin' and Miss Mayellerin' don't come to nothin', Mr. Finch."

She says to the jurors, in effect, if they want to be like Atticus, they can pretend to be men, but they are really cowards.

Yet Atticus is clearly the opposite of a "yellow stinkin' coward[]." He is the novel's hero, even though he explicitly rejects this central aspect of southern chivalry by defending Tom against Mayella's accusation. As I explain in greater detail below, he defends Tom by verbally attacking Mayella on cross-examination, seeking to expose her as a liar.

Third, southern men at the time notoriously romanticized the antebellum South and revered the Confederacy's war against the North as the great Lost Cause: "During the Civil War, Southern Spokesmen had hailed Johnny Reb for his devotion to ideals, his courage in battle, and his endurance of hardship. So pervasive was this eulogistic ideology that it not only survived defeat but actually increased its emotional appeal." ${ }^{\circ}$ One sign of this reverence was the many Civil War monuments in the South, honoring Southern soldiers. The peak years for unveiling these monuments occurred in the first two decades of the twentieth century, ${ }^{11}$ just before the events in the novel.

Atticus also embraces the idea of a lost cause, but it is not for the Confederacy. At one point, he tells Jem why he wanted him to spend time with the elderly Mrs. Dubose, to observe her break herself of her morphine addiction before dying: "I wanted you to see what real courage is, instead of getting the idea that courage is a man with a gun in his hand. It's when you know you're licked before you begin but you begin anyway and you see it through no matter what" (p. I28). The passage also 
describes Atticus' own lost cause, which is his fight for Tom Robinson. He explains to Scout: "Simply because we were licked a hundred years before we started is no reason for us not to try to win" (p. 87).

The connection between this lost cause and the Confederate one is made explicit when Scout replies, "You sound like Cousin Ike Finch." Scout explains that Ike is "Maycomb County's sole surviving confederate veteran. He wore a General Hood type beard of which he was inordinately vain." When they would visit him once a year,

Jem and I would listen respectfully to Atticus and Cousin Ike rehash the war. "Tell you, Atticus," Cousin Ike would say, "the Missouri Compromise was what licked us, but if I had to go through it agin I'd walk every step of the way there an' every step back just like I did before an' furthermore we'd whip 'em this time...." (p. 87)

As if he can undo the past, Ike refuses to quit despite the fact that the war is over, which is exactly parallel to Atticus's statement: "Simply because we were licked ... before we started" is no reason to give up. Southern chivalry demanded fighting for the underdog, and in some sense the ultimate underdog is one who has already lost. Yet, in Tom Robinson, Atticus champions the lost cause of an even bigger underdog, one that the Confederacy and the Jim Crow caste system stand against.

In these three respects, the novel offers a transformation of the markers of southern manliness into a new kind of hero: instead of the white man who violently protects white women from black predation and glories in the Lost Cause of the Confederacy, Atticus fights without violence for the lost cause of Tom Robinson, seeking to defend a black man from white predation rooted in the Confederacy. Stating the point in terms of chivalry identifies why the novel is less comfortable today: it valorizes the privileged white man who protects the helpless black man. Modern readers may understandably prefer a sweeping rejection of chivalry and a celebration of the heroic African Americans who stood up for their own civil rights, but the novel, set in small-town Alabama of 1935, offers a more limited transformation that was plausible in that time and place. Given the power of Jim Crow norms at this time, the novel offers not even a modest success but a heroic failure, in that Tom dies despite Atticus's efforts.

These three twists on white Jim Crow manliness seem fairly straightforward. But for the rest of this essay, I want to address a fourth and less obvious way the novel reconstructs manliness: by the strength of empathy in Atticus. 
Empathy is conventionally coded as a trait of womanhood. Social scientists and biologists debate the point, but some see evidence that woman are on average more empathetic than men; others claim that men and women are equally empathetic but that men are on average better able to disengage their empathetic concern or compassion for rivals and adversaries. ${ }^{12}$ Yet if we attend more carefully to empathy, we shall see that it has different elements, only one of which is feminine. In multiple characters but especially in Atticus, To Kill a Mockingbird explores types of empathy and draws our attention to their potentially dual role in lawyering.

The novel most directly refers to the gendered nature of empathy in the quotation that begins this essay. At one point, Aunt Alexandra is horrified to find that Jem and Scout have no special regard for the significance of their family origins. Jem has been lightheartedly discussing an embarrassing cousin Joshua, a sewer inspector, who was locked up for trying to shoot the president and thereby cost the family five hundred dollars, presumably in legal expenses (p. I50). The implication is that Joshua was perhaps not fully sane. Aunt Alexandra has a talk with Atticus, who that night stops by Jem's bedroom, with Scout present, to deliver a stern message. Fidgeting, he says: "Your aunt has asked me to try and impress upon you and Jean Louise that you are not from run-of-the-mill people" and that she plans to speak to them about their family history "so you'll have some idea of who you are, so you might be moved to behave accordingly" (p. I5I). Fidgeting as well, Scout runs the teeth of a comb against the edge of a dresser and Atticus curtly says "Stop that noise." At this point Scout begins to cry.

Eight-year-old children often cry without serious reason, and Scout does not verbalize any reason. As a narrator, however, she explains: "This was not my father. My father never thought these thoughts. My father never spoke so." Though she does - not speak, Atticus is able to grasp her thoughts and feelings and realizes that her disturbance is deep, that he has shaken her understanding of who her father is. So he abandons his sister's project and countermands his order, telling his children to "Forget it" (p. 152). He leaves the bedroom and then briefly returns to joke: "Get more like cousin Joshua every day, don't I? Do you think I'll end up costing the family five hundred dollars?" Scout then reports: "I know now what he was trying to do, but Atticus was only a man. It takes a woman to do that kind of work."

"The passage is not easy to interpret precisely. I read "that kind of work" to refer to the emotional work that parents do to raise children. Part of the work is to understand the thoughts and feelings of children, who cannot clearly express them. This is the work of empathy, which turns out to be a key theme of the novel. And it turns out that Atticus and other men in the novel are frequently quite competent at 
empathetic understanding of others. They frequently do "that kind of work." Before exploring the empathy theme in To Kill a Mockingbird, and its role in lawyering, I discuss the meaning of empathy.

\section{A. Two Aspects of Cognitive Empathy}

To say that empathy is feminine is too simple. Daniel Batson recently distinguished eight uses of the term empathy in the psychology literature. ${ }^{13}$ For my purposes, I draw on a simpler two-part distinction he makes. Batson says that researchers use the eight concepts of empathy to answer two questions: (I) "How can one know what another person is thinking and feeling?" And (2) "What leads one person to respond with sensitivity and care to the suffering of another?" ${ }^{14}$ The answer to both of these questions is empathy, but not the same kind of empathy.

The first question poses a cognitive issue and directs our attention to what may be called cognitive empathy. In some sense, cognitive emparhy is mind reading. ${ }^{15}$ One theory is that humans have a remarkable capacity to use a "theory of mind" to discover the thoughts and emotions occurring in another mind. Another theory is emotional contagion, in which an animal has the capacity to mirror the emotions of another (perhaps by first mimicking their outward behavior), and then to use introspection to infer what emotional state the other person must have. Humans probably have both sources of cognitive empathy, but it is clear that part of what lawyers or any strategic game player does is the former: to reason consciously about how the other person is reasoning and thereby to infer their thoughts and emotions.

By contrast, the second question raises not a cognitive but an emotional issue: What thoughts and emotions might cause an individual to engage in altruistic behavior? The question directs our attention to what might be called empatbetic con$c e r n$, an emotional engagement with another person that triggers concern when the other is in distress. Batson's major thesis is that emparhetic concern explains altruism, particularly behavior aimed at alleviating distress. Whether or not that is true, I simply want to distinguish the two dimensions of empathy, and to further distinguish these types of empathy from the behavior they might (or might not) produce. In a typical case, (I) cognitive empathy allows someone to recognize and understand another person's psychic suffering, which might produce (2) empatheric concern for their suffering, which might produce (3) compassionate behavior. But the connection between these three steps is at most a mere tendency, not a necessity.

Focus on (I) and (2). The empathy we code as feminine is the emotion of empathetic concern, while the insights of cognitive empathy are presumably masculine. Initially, note how they are conceptually distinct. Cognitive empathy need not lead to empathetic concern; the sadist might use cognitive empathy to understand better 
how to inflict psychic harm on a person. And empathetic concern might arise without cognitive empathy. $A$ might not be capable, on his own, of inferring $B$ 's thoughts and feelings, but if $B$ informs $A$ of her suffering, $A$ may take the report at face value and feel concerned for $B$. Nonetheless, cognitive empathy frequently leads to empathetic concern and empathetic concern may prompt the greater use of one's imagination-greater effort - to generate cognitive empathy.

Now consider the relationship between the first two mental steps and compassionate behavior. Even if $A$ (I) cognitively understands and (2) feels empathetic concern for $B$, that knowledge and emotion might fail to produce (3) compassionate behavior. Most obviously, if there are other motives pushing against the choice of compassion, $A$ may disregard his empathy for $B$. Indeed, not only can a person ignore the target of his cognitive empathy, but cognitive empathy can also make it possible to do a person greater harm. If you want to strategically manipulate or control adversaries, it helps a lot to understand their thoughts and feelings, so that you can anticipate their next move and stay one step ahead.

Some people find this claim so jarring that they object to the use of term "empathy" in this manner, even when qualified as "cognitive empathy." Yet there is nothing original in my using "empathy" to refer to the human ability to read the minds of other humans. Martha Nussbaum vividly made this point by discussing empathy with the example of a torturer, who we can imagine is better able to inflict pain and terror by understanding his victim's perspective. ${ }^{16}$ More generally, she notes that "enemies often become adept at reading the purposes of their foes and manipulating them for their own ends." This is also true in competitive games. Psychologist Paul Bloom uses the example of poker players: "Those who win the World Series [of Poker] are superb mindreaders. As [player Al] Alvarez says, 'One of the many gifts that separates the professionals from the amateurs is the ability to read their opponent's hands with uncanny accuracy from the tiniest clues: timing, position, the way their fingers move their chips or their eyes flicker, even the pulse beat in their neck." "17

The idea that empathy is feminine does not apply to cognitive empathy. Poker, for example, is a masculine activity. One wants to understand one's opponents so as to defeat them; this does not entail that one feels concern for taking their money. (One could feel such concern, but that would be a reason not to play the game, or not to win.)

As a third example of this distinction, consider the strategic advantage that cognitive empathy gives to police when they interrogate suspects. Interrogation is also a masculine activity. As in poker,,cognitive empathy helps the interrogator catch the suspect psychologically off-guard. A well-timed, dramatic revelation of an accusation may cause the unprepared guilty suspect to react involuntarily, with a blush or 
stammer, after which she gives up and confesses. The interrogator will have a better sense of how to time the revelation if she has a sense of the suspect's state of mind, which requires cognitive empathy.

There are also less obvious reasons the interrogator gains from taking the suspects' perspective. Police interrogation manuals recommend the technique of "moral minimization," where the detective proposes to the suspect a moral excuse for committing the crime, one that lessens its moral wrongfulness, so as to make it easier to confess. ${ }^{18}$ One manual, the "Reid Technique," recommends: "Sympathize with the Suspect by Saying that Anyone Else Under Similar Conditions or Circumstances Might Have Done the Same Thing... [T] he solicitations of a sympathetic investigator may allow the suspect to believe that if the investigator can understand the reasons for his or her crime, others may also be understanding." "19 Yet one can readily. see that this technique depends on understanding the suspect well enough to offer rationalizations that he will find convincing-perhaps the very rationalizations he already used to justify his crime to himself-because the suspect might correctly identify unconvincing rationalizations as clumsy efforts to manipulate him.

A more surprising advantage to cognitive empathy in interrogations is that empathetic police know they can sometimes succeed by an appeal to the conscience of the suspect. One of the most famous interrogations in Supreme Court law involved the "Christian burial speech" from Brewer v. Williams. ${ }^{20}$ On the day after Christmas, police arrested Willians for the murder of a ten-year old girl, Pamela Powers, who disappeared the day before Christmas. Police had not found the girl's body and it had begun to snow, which promised to make its recovery more difficult, perhaps impossible. During a long car ride back to the jurisdiction of the disappearance, a police detective, Leaming, attempted to interrogate Williams without his counsel being present. This was a rare opportunity, but Williams was resistant to speaking. The detective had to select one of a number of possible interrogation strategies for the situation. After taking a "read" of his suspect, Leaming sought to appeal to Williams' religious beliefs. In a rhetorically skillful speech, the detective asked that he allow the parents to give their daughter a "decent Christian burial," rather than leave the body out in the elements. It worked; Williams led the police to the body. ${ }^{21}$

Another example is Rhode Island v. Innis.2. Police there had arrested a man for murdering a cab driver with a shotgun. They suspected that he had hidden the shotgun in the area of a school for disabled children, but Innis had asserted his Miranda rights at the scene of the arrest, so the police could not interrogate him. So they tried something else. While several police officers were in a car with Innis transporting him to the stationhouse, one officer said to another something like: "[I]t would be too bad if... a girl-would pick up the gun, maybe kill herself." ${ }^{23}$ Hearing this, Innis spoke up and revealed where the shotgun was. 
In both cases, a capacity for cognitive empathy assists the police in their strategic manipulation of their suspect. Innis is particularly interesting because the legal question was whether the police tactic of speaking in the presence of the suspect, without actually addressing him, counted as "interrogation." If it did, then it violated Miranda. The Supreme Court thought that it depended on whether the police "should have known" their words or actions "were reasonably likely to elicit an incriminating response." ${ }^{324}$ Under that standard, the Court decided that these words were not interrogation.

When I've taught the case (elsewhere than at my current institution), some students agreed with the Court's conclusion by offering this reason: the police could not possibly have predicted that a man capable of murdering a cab driver with a shotgun for money would have cared that the gun he hid might injure a child. Whatever the right answer to the legal question, this particular rationale shows a basic failure of cognitive empathy. The world is not populated only by those who follow conventional morality and those who follow no morality; it includes violent men who follow their own moral code, a common feature of which is greater acceptance of stranger violence toward men than toward women or children (domestic violence is another matter). The police in these cases had more cognitive imagination than these particular students; the cognitive empathy here allowed them to succeed in interrogating the guilty.

\section{B. Male Empathy in To Kill a Mockingbird}

To Kill a Mockingbird shows us both compassionate and strategic uses of cognitive empathy. Although it is not surprising that the novel shows a man-Atticus-making strategic use of empathy, it also shows a variety of men whose empathetic concern motivates compassionate behavior, "that kind of work" ordinarily associated with women. Just as Atticus works at being both a father and a mother to this children (with Calpurnia's assistance), he exhibits both masculine and feminine forms of empathy.

To begin, Atticus tries to teach Scout empathy. One of the famous lines of the novel is when Atticus says: "[I] fyou can learn a simple trick, Scout, you'll ger along a lot better with all kinds of folks. You never really understand a person until you consider things from his point of view... until you climb into his skin and walk around in it" (p. 33). Scout and Atticus refer back to this idea of perspective taking at various points. At one point when Jem is uncommunicative, Scout comments: "As Atticus had once advised me to do, I tried to climb into Jem's skin and walk around in it" (p. 65). In this case, she comes to understand that she would also be quiet if she were in his position (having just had a frightening encounter at the Radley house) and so 
she leaves him alone. When Jem asks Atticus why he did not respond to Bob Ewell's provocation - the spit in the face-Atticus replies: "Jem, see if you can stand in Bob Ewell's shoes a minute" (p. 249). Atticus explains that he destroyed Bob's credibility at the trial, so he had to have some kind of "comeback", some victory, to get even. Atticus would rather that Bob's victory be spitting in Atticus' face than beating one of the Ewell children. The metaphor of "walking in another's shoes" (or skin) gets a final reference I discuss below.

Atticus' empathy generally motivates compassionate and altruistic behavior. As I've already indicated, with the passage leading up to Scout's statement "It takes a woman to do that kind of work," he is an empathetic and caring parent who understands his children well. There are many other examples of compassionate parenting, but Atticus' empathy also extends outside his family. When Scout brings home her classmate Walter Cunningham, Jr., who is awkward in this wealthier environment, Atticus understands the boy sufficiently that they can converse like "two men talking about crops" (pp. 26-27), though Atticus is not a farmer. He is compassionate toward the Radley family when he tries at various points to reign in his children's interest in Boo to prevent them from causing the family anxiety. He is compassionate toward his elderly neighbor Mrs. Dubose by helping her end a morphine addiction before she dies (in part, by sending Jem to read to her). The list goes on. ${ }^{25}$

Other men also show important instances of empathy-based compassion. Boo Radley, who appears to be mentally challenged, exhibits some impressive empathy-based reasoning. One night, Jem, Scout, and Dill prowl around the Radley house only to run away in panic when they are discovered. Jem gets his pants caught and torn in a fence, and so he pulls out of them. Larer, he goes back to retrieve the pants and discovers them neatly folded over the fence with the torn part resewn. When he tells Scout, "Jem shudder[s]" and says "Like somebody was readin' my mind... like somebody could tell what I was gonna do. Can't anybody tell what I'm gonna do lest they know me, can they, Scout?" (p. 66). But of course a refined sense of cognitive empathy is a kind of mind reading. Boo does this again during the fire that burns Miss Maudie's house. Because it not safe to stay inside the nearby houses, Jem and Scout are standing outside in the cold near the Radley house, watching the men fight the fire across the street. Apparently, Boo divines that they are uncomfortably cold, because he unobtrusively walks up behind them and puts a blanket on their shoulders (pp. 80-82).

Tom Robinson is compassionate toward Mayella (if we believe his testimony). He walks past her house almost every day and he stops on many occasions to render some service because he recognizes that she's overwhelmed: "Seemed like every time I passed by yonder she'd have some little somethin' for me to do-choppin' kindlin', totin' water for her....Mr. Ewell didn't seem to help her none, and neither did 
the chillum" (p. 218). Jem also shows empathy-based compassion in various ways. Perhaps the most striking example is when, late in the novel, he asks Scout not to kill an insect, a "roly-poly," because "they don't bother you" (p. 273). This causes Scout to comment: "Jem was the one who was getting more like a girl every day, not I," raising again the notion that empathy and compassion are feminine while locating it in men.

The theme of empathy is so important to the novel that all of the key events, by my count, can be seen as involving the dramatic use or failure of cognitive empathy. One such instance occurs when Atticus stands up to the lynch mob that has come to the jail to take Tom. The appearance of Scout, Jem, and Dill does not immediately defuse the situation, but it eventually does so when Scout recognizes Walter Cunningham, Sr., and asks him to pass on her regards to his son, Walter, Jr. Scout does not understand why, but it causes the mob to break up. The next day, Atticus explains, again using his empathy metaphor: "you children last night made Walter Cunningham stand in my shoes for a minute. That was enough" (p. 179). The individuals in the mob obviously lack (cognitive or emotional) empathy for Tom, but their empathy for Atticus is sufficient. Scout's mention of the child Walter must have at least made the father Walter Cunningham take the perspective of Atticus, who had to be terrified at the fact that his children were standing in the middle of a lynch mob.

Now consider two pivotal failures of empathy. First is the central encounter between Tom and Mayella, the day he stops by the house and Mayella winds up accusing him of rape. According to Tom's testimony, Mayella attempted and failed to seduce him. Despite Tom's compassion for her, at the critical moment he does not understand her well enough to divine her intentions. If he had, he would no doubt have never agreed to enter her house, and that would have saved his life. In return, Mayella does not understand Tom well enough to anticipate his rejection of her, or she would never have invited him into her house. On the witness stand, Tom recounts a particular part of the misunderstanding. He asks Mayella where her siblings are and she explains that she had saved money for a year to send them to town for ice cream. Tom testifics that he then said: "why Miss Mayella, that's right smart o'you to treat 'em. An' she said, 'You think so?'” (p. 220). Tom comments to Atticus "I don't think she understood what I was thinkin'-I meant it was smart of her to save like that, an' nice of her to treat 'em.' " Atticus replies: "I understand you, Tom. Go on." The point is, however, that at the time, Mayella did not understand. She thought Tom was complimenting her on devising a way for the two of them to be alone.

The last major event in the book is Bob Ewell's attempted murder of Scout and Jem, and here everyone, including Atticus, is guilty of an epic failure of cognitive 
empathy. Atticus cannot imagine that Bob would attack his children, or he would never have let them walk alone in the dark to the school pageant. The failure is explicit. When Aunt Alexandra previously expressed a concern about Bob, Atticus replies, "What on earth could Ewell do to me, sister?" (p. 250). When Atticus first learns of the attack on Jem, he says he can't "conceive" of anyone "low-down enough to do a thing like this" (p.305). And when he learns the perpetrator is Bob, he repeats that he "can't conceive of a man who'd" do such a thing (p. 308). Yet we can forgive this lapse in cognitive empathy. It is not inconsistent with my general claim that he possesses a powerful empathetic imagination because the behavior Atticus failed to anticipate is so shocking and rare. Atticus correctly understood that Bob was the sort of man who must have some kind of satisfaction for his courtroom humiliation and understood that without this satisfaction he might take it out on children. $\mathrm{He}$ simply never imagined that Bob's misplaced and cowardly violence might include murdering Scout and Jem.

So I have described the role of empathy-its dramatic presence or absencein three key events: Atticus' successful confrontation of the lynch mob; the Mayella-Tom encounter that led to the rape accusation; and Bob's attempted murder of Scout and Jem. Now let us turn to the other major event of the novel, the trial. Here we see the other side of empathy. Atticus' perspective taking is useful for anticipating and controlling strategic adversaries, as by extracting information they do not want to give away.

\section{The Cross-Examination of Mayella Evell}

Atticus does a more effective job of cross-examining Mayella Ewell because of his understanding of her and her tragic predicament. His cognitive empathy allows him to grasp more precisely Mayella's motivation for falsely accusing Tom of rape, which allows him to ask the relevant questions to expose that motivation to the jury. As we shall see, his empathy is double-edged because it also makes him more aware of the suffering he inflicts on Mayella by doing his job.

The starting point is a question that has been insufficiently examined in the critical literature: What does Atricus know about Mayella? Every novel challenges the reader to use empathy to fill in the gaps the author leaves (intentionally or unintentionally) in the description of the characters' thoughts and feelings, but a novel like To Kill a Mockingbird goes two steps farther. First, we receive the story from an unreliable narrator, the eight-year-old Scout, whose limitations place extra interpretive demands on the reader. ${ }^{26}$ An unreliable narrator creates an especially strong invitation to use imaginative empathy to fill the gaps in the child's understanding of the events. Second, the story gives us a theme of empathy and a powerfully empathetic 
character in Atticus. So it is particularly important to ask what obscure elements in the story come to light if we follow Atticus in exercising our cognitive empathy. What does he know that Scout doesn't? Or what does the adult Scout now realize, decades later, that she did not know at the time?

Once we set aside the happenstance that Scout is the one telling us the story, the first thing to notice is the centrality of an event that does not include her. The original cause of the other key events is the encounter between Mayella Ewell and Tom Robinson that leads her to accuse him of rape. Because the event occurs "off stage," the novel forces us to imagine them, as the trial forces the jurors to imagine them.

If Tom is guilty, the event is an all-too-common rape and we can easily understand why he lies about the matter and his lies tell us nothing about Mayella. But if Tom is telling the truth-the conventional understanding of the story-then the result is that Mayella and the event are more complex. ${ }^{27}$ Why did she risk so much by flouting the racial taboo of her community? Having been attracted to Tom, why does she now accuse him of a capital crime (as rape was in Alabama at this time)? Although the child Scout doesn't even ask these questions, I read Tom's testimony as providing just enough detail for us to answer them. Seeing things from Mayella's perspective shows how the event is more momentous and tragic than Scout understands it to be.

The first thing Atticus and perhaps everyone in Maycomb know about Mayella is her misery. Her mother died when she was young (like Scout), leaving her to cope with a vile and violent father (unlike Scout). Bob Ewell spends much of the family welfare check on alcohol. The Ewells live near the town dump, which they scour every day for things of value. Mayella is the oldest sibling and must work hard to care for her five to eight siblings (p. 194).. ${ }^{.8}$ The only one of these siblings we meet is Burris Ewell, at the first day Scout goes to school, where his parting words to his teacher are, "Ain't no snot-nosed slut of a schoolteacher ever born c'n make me do nothin'!" (p. 3I). Thus, we can understand why Mayella thinks that Atticus mocks her in his cross-examination when he uses polite terms such "ma'am" and "Miss" (p. 206). It is unlikely that any males in her family ever show her that kind of respect.

On top of this, it appears that her father, Bob, physically abuses Mayella. And there is some reason to think that the abuse includes incest. When Tom describes their encounter, he says that Mayella said to him that she had "never kissed a grown man before.... She says what her papa do to her don't count" (p. 221; emphasis added). The ominous words "to her" in this sentence seem to accuse Bob, but even if the sentence omitted them, there are other grounds for suspicion. Bob seems an unlikely source of affectionate fatherly kisses. When the prosecutor asks him on the witness stand the simple question, "Are you the father of Mayella Ewell?" his immediate answer is unsentimental and insinuating: "Well, if I ain't I can't do nothing about it now, her ma's dead" " (p. 195). It also seems odd that Mayella would even 
contemplate her father's kisses during her encounter with Tom, much less feel the need to distinguish them from the passionate kisses she is asking Tom for, unless there was something sexual about them. We know from Atticus that the Maycomb authorities do not always require the Ewells to obey laws they enforce against everyone else (p. 34). Although the specific examples mentioned are only truancy and poaching, Miss Maudie reminds us at one point: "The things that happen to people we never really know. What happens in houses behind closed doors, what secrets" (p. 5I).$^{29}$ Though some commentators think the incest is obvious, ${ }^{30} \mathrm{I}$ regard the issue as not definitively settled, one of the horrors "we never really know." My point is that the grounds for suspicion would not escape the attention of Atticus. He understands the situation as well as it can be understood by an outsider.

There is a second fact Atticus knows about Mayella. A person in her situation could easily be resigned to her fate, but she is-before the final encounter with Tom-resilient and hopeful. We get a hint of this when we learn of her geraniums. The area around the Ewell cabin is littered with junk gleaned from the dump, such a large assortment of broken and rusted items that it made the yard "look like the playhouse of an insane child" (p. 194). But there is one exception that "bewildered Maycomb." In one corner, "[a]gainst the fence, in a line, were six chipped-enamel slop jars holding brilliant red geraniums, cared for as tenderly as if they belonged to Miss Maudie Atkinson... People said they were Mayella Ewell's" (p. 194). Tom tells us: "She watered them red flowers every day-" (p. 218). A person who had given up hope would presumably not bother to create a small thing of beauty in such an ugly setting, not when she is barely eking out a life. Somehow Mayella has not, before the last encounter with Tom, let her poverty, ignorance, and abuse overwhelm and defeat her.

More astonishing is the self-possessed, hopeful way that she acts on her attraction to Tom (according to his testimony). She is not daunted by the monumental barriers of the Jim Crow racial taboo and Tom's married status. She cannot successfully seduce Tom under the watchful eyes of her siblings, so Mayella starts by hatching a plan. She saves enough money so that, on the day she will ask Tom inside, she can first send all her siblings into town to get ice cream. Here is a pertinent fact that slips in through the testimony of Tom: it takes her an entire year. "She says, 'Took me a slap year to save seb'm nickels, bur I done it" (p. 220). Surely, it required extraordinary patience and sacrifice on her part-during the Great Depression-to save money. And to keep her father from discovering what she was up to because Bob Ewell would never have let her keep any money she saved, even if he did not discover the illicit purpose. In context, this hope and patience is particularly striking. A stereotype of the poor is that they are lazy and impulsive. Mayella is obviously neither. Surely, there were many temptations to spend the money along the way, but 
she resisted them all. And many victims of domestic battering are overwhelmed by the apparent omnipotence of their batterer; they become passive and helpless. Yet again Mayella is assertive and proactive.

So we arrive at the day when Mayella put her daring plan into motion. Atticus obviously discussed with Tom the details of his encounter with Mayella. We see his preparation in his direct examination of his client. In preparing his cross-examination, he would have asked himself why Mayella did what she did. Inevitably, he would have imagined the day from her perspective, walked around in her skin. Quite probably, Atticus realized that some point in this day was, and would always remain, the happiest moment of Mayella Ewell's life. Perhaps it occurred when her siblings first departed for ice cream, leaving her alone in a strangely quiet home. Maybe it was the moment when Tom first appeared on the road, proving that she had not wasted the hard-earned seven nickels just given to her siblings to get them out of the way. Or possibly it was when Tom accepted her invitation to enter the house, or when she hugged and kissed him, the first time she kissed a man other than her father, the first time she wanted to. While things were moving according to plan, Mayella must have felt an unfamiliar and exhilarating sense of control of her life.

For Atticus, the paragon of empathy, it could not have escaped him that, at this point, the two worst possible things that could happen to Mayella did happen. First, Tom rejects her. The only man ever to show her respect, a good-looking, slightly older man whose kindness she thought reflected romantic interest, utterly spurns her advance. Ironically, the same racial norms that encouraged him to show respect and kindness to Mayella, thus prompting her attraction, compelled him to avoid her advance. (Not that we can assume he wanted to reciprocate; like Mayella, we have no good reason to think he was attracted to her.)

Second, as Tom rejects her, Bob Ewell appears at the window. Tom says that Bob called her a "goddamn whore" and threatened her life (p. 22I). She will have no sexual interlude with Tom, but her father will beat her as if she had. She will live in the worst of both worlds, being punished for something she had wanted but never obtained. If her nine-year-old brother Burris is willing to call his teacher a slut at school, one can imagine the kind of taunting Mayella must endure from her brother(s) and father, especially when Bob is drunk and especially if he has been sexually abusing her. After Tom runs off, the beating Bob gives her is surely not the last to be inspired by the embrace he saw.

For Mayella, these events are annihilating. Mockingbird is a story of how racism kills Tom Robinson, but there is a parallel story of the death of Mayella's hope and resilience. She risked everything and lost. Of course, none of this justifies her falsely accusing Tom of rape. But imagining her story at least makes her lie less of a puzzle. First, it is not difficult to imagine Bob conceiving the sadistic plan to punish 
Mayella and Tom by forcing her to be an instrument in his destruction. Second, however wrongful, Mayella cannot stand to see the man who rejected and humiliated her walk by her house every day for the rest of her life. Having been spurned by a low-status black man, she agrees to call in her one status claim as a white woman, which is to be believed when she accuses a black man of rape. Of course, even that claim fails, despite the jury's conviction, because it appears later that many of the white people in Maycomb did not believe her. And that is largely because of the cross-examination by Atticus.

The cross-examination is effective in several respects. I want to draw attention to one narrow part it, when Atticus poses a simple question that only someone who imagines Mayella's life would ask. "Miss Mayella,' said Atticus ... 'a nineteen-year-old girl like you must have friends. Who are your friends?" (p. 208; emphasis added). Following the standard advice, Atticus doesn't ask this question without knowing the answer. He knows the answer is that she has no friends, which is why Mayella responds only with: "Friends?" Atticus tries again: "Yes, don't you know anyone near your age, or older, or younger? Boys and girls? Just ordinary friends?" This time her hostility "flared again" and she replies: "You makin' fun o'me agin, Mr. Finch?" (p. 208). Having empathized with her life, Atticus knows that this fact helps to explain the desperation of her behavior, why she would risk so much on the fantasy that Tom was sexually interested in her. Showing the jury her desperation would therefore make Tom's story more credible.

So this is the lawyer's job: in front of the whole town turned out to watch the trial, to ask a friendless person the devastating question, "Who are your friends?" To expose to everyone that this impoverished, uneducated, overworked, beaten, possibly sexually abused person lacks any romantic partner or ordinary friend. No wonder that Scout reports: "When Atticus turned away from Mayella he looked like his stomach hurt" (p. 213). And later:

Somehow, Atticus had hit her hard in a way that was not clear to me, but it gave him no pleasure to do so. He sat with his head down, and I never saw anybody glare at anyone with the hatred Mayella showed when she left the stand and walked by Atticus's table. (p. 214)

A few critics have inferred from his actions that Atticus is indifferent to Mayella's suffering, perhaps out of class blindness. ${ }^{31}$ But I am inclined to say that he is not that lucky. If one's role as a lawyer requires that one harm an adverse witness by exposing the person's failings, it would be professionally fortunate not to feel the pain one is inflicting. If one must ask a pitiless question, it would be easier if one is genuinely without pity, like the poker player who feels no concern for the people whose 
money he wins. But that does not describe Atticus. Given his combination of cognitive empathy and empathetic concern, he is the single person in the courtroom who is most likely to fully grasp Mayella's misery and desperation, to understand why she misinterpreted Tom's kindness as sexual interest, and to imagine how she was utterly destroyed by his rejection.

This is the conundrum of the trial lawyer. Having cognitive empathy will make one a better lawyer because it will allow one to get inside the head of adversaries (witnesses and opposing counsel). But for the decent and compassionate lawyer, the job will often require suppression of the empathetic concern one's cognition inspires. In legal combat, the lawyer's empathetic imagination is sometimes just a tool for attack, damaging a person who, he may believe, deserves compassion. And this is the conundrum of Atticus: there is no way to defend Tom Robinson except to be merciless on the woman whose testimony threatens to send him to the electric chair. As Atticus says to his sister, he is "in favor of Southern womanhood as much as anybody, but not for preserving polite fiction at the expense of human life" (p. 167). As he tells the jury: "I have nothing but pity in my heart for the chief witness for the state, but my pity does not extend so far as to her putting a man's life at stake" (p. 23r).32 So he exposes Mayella as a liar, a violator of the racist and sexual taboos of her community, and a failure rejected by the black man she seeks to seduce.

Let me conclude by connecting this empathy theme back to the manliness thesis. The final part of Harper Lee's reconstructed masculinity, the final inversion of southern chivalry, is that Atticus not only refuses to take the side of white womanhood against a black man but also actively harms a particular white woman. The last part of his heroism is his willingness to "man up" to do this unpleasant, lawyering job despite this knowledge and despite his inclination for compassion. This is what makes Scout's description of the cross-examination so significant. With room for the hypocrisy of domestic violence, it was considered cowardly, and contrary to chivalry, for a man to hit a woman. Yet Atticus' cross-examination of Mayella "hit her hard" and was heroic for doing so. The irony is that it is his empathetic insight into Mayella that allows him to hit her as hard as he does.

\section{NOTES}

* Bernard D. Meltzer Professor, Aaron Director Research Scholar, University of Chicago Law School. I thank Mary Anne Frank, Saul Levmore, Anna-Maria Marshall, Naomi Mezey, Robin West, and participants at the University of Chicago Conference on Manhood in American Law and Literature, the faculty workshop at Tulane University School of Law, and Professor West's law-and-literature seminar for astute and challenging comments on prior drafts. 
1. Harper Lee, To Kill a Mockingbird (New York: Harper Perennial, 2006), 152. All in-text citations are to this edition.

2. Recent discussions emphasize the role of empathy in judging. See, for example, Susan Bandes, "Empathetic Judging and the Rule of Law," Cardozo Law Review De Novo (2009), http://www.cardozolawreview.com/content/denovo/BANDES_2009_133.pdf; Robin West, "The Anti-Empathic Turn," in Passions and Emotions, ed., James E. Fleming (New York: NYU Press, 2013).

3. See Michael Warner, "Manning Up" (Chapter 8 of this volume).

4. See Martha C. Nussbaum, "Jewish Men, Jewish Lawyers: Roth's 'Eli, the Fanatic' and the Question of Jewish Masculinity in American Law" (Chapter 9 of this volume).

5. Perhaps there is a childhood anecdote Harper Lee is drawing on, as her childhood friend Truman Capote (the basis of the character Dill) used the term "morphodyte" in his 195I novel. See Truman Capote, The Grass Harp (New York: Vintage International, 2012), 4 ("One of the stories [Papa] spread, that Verena was a morphodyte, has never stopped going around...."). But there are earlier examples. The southern writer Carson McCullers used the term "morphidite" in her 1946 story The Member of the Wedding (New York: First Mariner Books, 2004), 20, and Nelson Algren used the term "murphydyke" in his 1949 novel The Man with the Golden Arm (New York: Seven Stories Press, 1996), 224.

6. See John Dollard, Caste and Class in a Southern Town (Madison: University of Wisconsin Press, 1937), 176-77 ("[W] hite people become aggressive as soon as Negro submission is withheld, and many stories are told of the 'what I did with that "uppity" nigger' type."); Arthur Raper, The Tragedy of Lynching (Chapel Hill: University of North Carolina Press, 1933), 48 ("The Negro must stay in his place' is a common phrase, and the white people who have defined 'his place' may be expected to react violently if they think he is either getting out of it or showing dissatisfaction with it."); Gunnar Myrdal, An American Dilemma (New York: Harper \& Row, 1944), 563 ("Economic fear is mixed with social fear: a feeling... [that] the white man's social status is being threatened and is in need of defense.... [T] his feeling [underlies the] common saying...that 'a lynching now and then' is expedient or necessary in keeping the Negroes from becoming 'uppity." "); Walter White, Rope and Faggot: A Biography of Judge Lynch (New York: Arno Press, 1969), II (suggesting that "lynching is much more an expression of southern fear of Negro progress than of Negro crime").

7. See, for example, Richard E. Nisbett and Dov Cohen, Culture of Honor: The Psychology of Violence in the South (Boulder, CO: Westview Press, 1996); Dov Cohen and Richard E. Nisbett, "Self-protection and the Culture of Honor: Explaining Southern Homicide," Personality and Social Psychology Bulletin 20 (1994): 551-67; Dov Cohen et al., "'When You Call Me That, Smile!' How Norms for Politeness, Interaction Styles, and Aggression Work Together in Southern Culture," Social Psychology Quarterly 62 (1999): 257-75.

8. Arthur Raper, The Tragedy of Lynching, 20.

9. See Jacquelyn Dowd Hall, Revolt against Chivalry: Jessie Daniel Ames and the Women's Campaign Against Lynching (New York: Columbia University Press, 1993).

Io. J. P. Radford, "Identity and Tradition in the Post-Civil War South", Journal of Historical Geography 18 (1992): 91-103.

I1. See Stephen Davis, "Empry Eyes, Marble Hand: The Confederate Monument in the South," Journal of Popular Culture 16 (1982): 2-21. 
12. See, for example, Frans de Waal, The Age of Empathy (New York: Three Rivers Press, 2009); Sarah Blaffer Hrdy, Mothers and Others: The Evolutionary Origins of Mutual Understanding (Cambridge: Harvard University Press, 2009).

13. See C. Daniel Batson, Altruism in Humans (New York: Oxford University Press, 2011), II-19.

14. See C. Daniel Batson, "These Things Called Empathy: Eight Related But Distinct Phenomena," in The Social Neuroscience of Empathy, ed. Jean Decety and William Ickes (Cambridge: MIT Press, 2009): 3-16.

15. See, for example, William Ickes, Everyday Mind Reading: Understanding What Other People Think and Feel (Amherst, NY: Prometheus Books, 2003).

16. See Martha C. Nussbaum, Upheavals of Thought: The Intelligence of Emotions (New York: Cambridge University Press, 200r), 329.

17. Paul Bloom, Descartes' Baby (New York: Basic Books, 2004), 3-4. The same is true of negotiations. See Adam D. Galinsky et al." "Why It Pays to Get Inside the Head of Your Opponent: The Differential Effects of Perspective Taking and Empathy in Negotiations," Psychological Science 19 (2008): $378-84$.

r8. See, for example, Saul M. Kassin et al., "Police Interviewing and Interrogation: A Self-Report Survey of Police Practices and Beliefs," Law \& Human Bebavior 31 (2007): 381-400; Richard A. Leo, "Inside the Interrogation Room," Criminal Law \& Criminology 86 (1996): 266-303.

19. See, for example, Fred E. Inbau et al, Essentials of the Reid Technique: Criminal Interrogation and Confessions (Sudbury, MA: Jones \& Bartlett Learning, 2005), 141-50.

20. 430 U.S. 387 (1977).

2r. 'The Supreme Court held that the interrogation violated Williams' Sixth Amendment rights to counsel and suppressed the confession. In a later decision, the Supreme Court held that the prosecutor could use the victim's body as evidence because it would have been inevitably discovered even without the unlawful interrogation. See Nix v. Williams, 467 U.S. 431 (1984).

22. 446 U.S. 291 (1980).

23. Ibid., 295 .

24. Ibid., 303 .

25. There is dissent from the heroic view of Atticus Finch (AF), based on various criticisms, primarily that he did too little to challenge the racism of his community. See, for example, Monroe H. Freedman, "Atticus Finch-Right and Wrong," Alabama Law Review 45 (1994): 473-82; Steven Lubet, "Reconstructing Atticus Finch," Michigan Law Review 97 (1999): 1339-77; Malcolm Gladwell, "The Courthouse Ring: Atticus Finch and the Limits of Southern Liberalism," New Yorker, Aug. 10, 2009, http://www.newyorker.com/reporting/2009/08/10/0908rofa_fact_ gladwell. For replies, see Randolph N. Stone, "Atticus Finch, in Context," Michigan Law Review 97 (1999): 1378-81; Abbe Smith, "Defending Articus Finch," Legal Ethics 14 (2011): 143-67. Relevant here is one point that cuts against my claim that AF is empathetic. Freedman says that AF fails to understand the trauma suffered by the Jewish family, the Levys, when masked Klan members paraded by their house years before, because he dismisses the incident so lightly (pp. 166-67). See Freedman, "Atticus Finch-Right and Wrong," 475. At the time, AF is speaking to his children, who fear that their only living parent is in physical peril from a mob; the obvious interpretation is that he seeks to reassure them by downplaying the danger the Klan poses. Freedman responds that AF has previously endorsed telling children the truth, chiding his brother for failing to answer a question from Scout ("What's a whore-lady?" p. 99). Ibid., 476. 
This pro-truth position is supposed to prove that AF revealed his actual views about the Klan and the Levys. That a parent might strongly fayor answering a child's socially awkward questions, but still prefer to shield them from terrifying truths, seems not to occur to Freedman, such is his commitment to a particular reading of the novel.

26. The narrator is complex because, from the first page, we learn that Scout is now older"enough years have gone by to enable us [Scout and Jem] to look back on" the events in the story (p. 3). We get further hints throughout the novel that Scout is now an adult. But the point is that she tells the story from the perspective she had as a child, identifying only what she understood then.

27. Part of the lawyers' revisionism about Atticus Finch is the argument that Mayella Ewell might be telling the truth and that Atticus is attacking her in the defense of a guilty Tom Robinson. See Lubet, "Reconstructing Atticus Finch," 1346-49 (describing the defense as "she wanted it"); Gladwell, "The Courthouse Ring: Atticus Finch and the Limits of Southern Liberalism" (recounting Lubet's arguments). To put it mildly, there are myriad problems here. See Smith, "Defending Atticus Finch"; Stone, "Atticus Finch, in Context." In what follows, I merely add the point that we gain much deeper insight into the character of Mayella and her tragedy, not less, if we take Tom's testimony as true.

28. "Nobody was quite sure how many children were on the place. Some people said six, others said nine" (p. 194). I am assuming that Mayella counts as a child in this accounting, but if not, she has six to nine siblings. She saves seven nickels for them all to get ice cream (p. 220), so the correct number is probably five or seven (being integers divisible into $35 \%$ ).

29. The novel may be priming us to consider the possibility of incest by the mention of the word "incestuous," where the Ewells are also mentioned (p. 147). The context is that Aunt Alexandra has been declaiming the different defects of Maycomb families by saying they have some kind of "Streak," for example "a Drinking Streak, a Gambling Streak, a Mean Streak, a Funny Streak." When she says that Miss Stephanie Crawford's nosiness is hereditary, Atticus brings her up short by stating: "Sister, when you stop to think about it, our generation's practically the first in the Finch family not to marry its cousins. Would you say the Finches have an Incestuous Streak?" The Ewells are mentioned seven lines later, where Jem comments that if the standard for being "Fine Folk" was living three generations on the same patch of land, then the Ewells qualify (for living that long next to the dump). Note the possible parallel: the Finches are ironically said to be incestuous but are actually "Fine Folk," so perhaps the fact that the Ewells are ironically said to be "Fine Folk" implies that they are incestuous.

30. See, for example, Iris Halpern, "Rape, Incest, and Harper Lee's To Kill a Mockingbird: On Alabama's Legal Construction of Gender and Sexuality in the Context of Racial Subordination," Columbia Journal of Gender \& Law 18 (2009): 743-806, 768.

31. See, for example, Lubet, "Reconstructing Atticus Finch," 1359 (claiming that Atticus Finch was "not able to comprehend the class and gender prejudices that suffused his work").

32. This is an important statement. Atticus' defense runs a risk. By showing the jury a little of the desperation of Mayella's life, he must also pull back the jury from being so compassionate toward her that, despite disbelieving her story, they convict Tom out of pity for Mayella. Perhaps this is why Atticus seems to contradict himself later in his closing argument by saying he "cannot pity her" (p. 23I). 
Readers with comments may address them to:

Professor Richard H. McAdams

University of Chicago Law School

1111 East 60th Street

Chicago, IL 60637

rmcadams@uchicago.edu 


\section{The University of Chicago Law School Public Law and Legal Theory Working Paper Series}

For a listing of papers 1-400 please go to http://www.law.uchicago.edu/publications/papers/publiclaw.

401. Gary Becker, François Ewald, and Bernard Harcourt, "Becker on Ewald on Foucault on Becker” American Neoliberalism and Michel Foucauilt’s 1979 Birth of Biopolitics Lectures, September 2012

402. M. Todd Henderson, Voice versus Exit in Health Care Policy, October 2012

403. Aziz Z. Huq, Enforcing (but Not Defending) “Unconstitutional” Laws, October 2012

404. Lee Anne Fennell, Resource Access Costs, October 2012

405. Brian Leiter, Legal Realisms, Old and New, October 2012

406. Tom Ginsburg, Daniel Lnasberg-Rodriguez, and Mila Versteeg, When to Overthrow Your Government: The Right to Resist in the World's Constitutions, November 2012

407. Brian Leiter and Alex Langlinais, The Methodology of Legal Philosophy, November 2012

408. Alison L. LaCroix, The Lawyer's Library in the Early American Republic, November 2012

409. Alison L. LaCroix, Eavesdropping on the Vox Populi, November 2012

410. Alison L. LaCroix, On Being “Bound Thereby,” November 2012

411. Alison L. LaCroix, What If Madison had Won? Imagining a Constitution World of Legislative Supremacy, November 2012

412. Jonathan S. Masur and Eric A. Posner, Unemployment and Regulatory Policy, December 2012

413. Alison LaCroix, Historical Gloss: A Primer, January 2013

414. Jennifer Nou, Agency Self-Insulation under Presidential Review, January 2013

415. Aziz Z. Huq, Removal as a Political Question, February 2013

416. Adam B. Cox and Thomas J. Miles, Policing Immigration, February 2013

417. Anup Malani and Jonathan S. Masur, Raising the Stakes in Patent Cases, February 2013

418. Ariel Porat and Lior Strahilevits, Personalizing Default Rules and Disclosure with Big

Data, February 2013

419. Douglas G. Baird and Anthony J. Casey, Bankruptcy Step Zero, February 2013

420. Alison L. LaCroix, The Interbellum Constitution and the Spending Power, March 2013

421. Lior Jacob Strahilevitz, Toward a Positive Theory of Privacy Law, March 2013

422. Eric A. Posner and Adrian Vermeule, Inside or Outside the System? March 2013

423. Nicholas G. Stephanopoulos, The Consequences of Consequentialist Criteria, March 2013

424. Aziz Z. Huq, The Social Production of National Security, March 2013

425. Aziz Z. Huq, Federalism, Liberty, and Risk in NIFB v. Sebelius, April 2013

426. Lee Anne Fennell, Property in Housing, April 2013

427. Lee Anne Fennell, Crowdsourcing Land Use, April 2013

428. William H. J. Hubbard, An Empiritcal Study of the Effect of Shady Grove v. Allstate on Forum Shopping in the New York Courts, May 2013

429. Daniel Abebe and Aziz Z. Huq, Foreign Affairs Federalism: A Revisionist Approach, May 2013

430. Albert W. Alschuler, Lafler and Frye: Two Small Band-Aids for a Festering Wound, June 2013

431. Tom Ginsburg, Jonathan S. Masur, and Richard H. McAdams, Libertarian Paternalism, Path Dependence, and Temporary Law, June 2013

432. Aziz Z. Huq, Tiers of Scrutiny in Enumerated Powers Jurisprudence, June 2013 
433. Bernard Harcourt, Beccaria's On Crimes and Punishments: A Mirror of the History of the Foundations of Modern Criminal Law, July 2013

434. Zachary Elkins, Tom Ginsburg, and Beth Simmons, Getting to Rights: Treaty

Ratification, Constitutional Convergence, and Human Rights Practice, July 2013

435. Christopher Buccafusco and Jonathan S. Masur, Innovation and Incarceration: An Economic Analysis of Criminal Intellectual Property Law, July 2013

436. Rosalind Dixon and Tom Ginsburg, The South African Constitutional Court and SocioEconomic Rights as 'Insurance Swaps', August 2013

437. Bernard E. Harcourt, The Collapse of the Harm Principle Redux: On Same-Sex Marriage, the Supreme Court's Opinion in United States v. Windsor, John Stuart Mill's essay On Liberty (1859), and H.L.A. Hart’s Modern Harm Principle, August 2013

438. Brian Leiter, Nietzsche against the Philosophical Canon, April 2013

439. Sital Kalantry, Women in Prison in Argentina: Causes, Conditions, and Consequences, May 2013

440. Becker and Foucault on Crime and Punishment, A Conversation with Gary Becker, François Ewald, and Bernard Harcourt: The Second Session, September 2013

441. Daniel Abebe, One Voice or Many? The Political Question Doctrine and Acoustic Dissonance in Foreign Affairs, September 2013

442. Brian Leiter, Why Legal Positivism (Again)? September 2013

443. Nicholas Stephanopoulos, Elections and Alignment, September 2013

444. Elizabeth Chorvat, Taxation and Liquidity: Evidence from Retirement Savings, September 2013

445. Elizabeth Chorvat, Looking Through' Corporate Expatriations for Buried Intangibles, September 2013

446. William H. J. Hubbard, A Fresh Look at Plausibility Pleading, March 2015

447. Tom Ginsburg, Nick Foti, and Daniel Rockmore, "We the Peoples": The Global Origins of Constitutional Preambles, March 2014

448. Lee Anne Fennell and Eduardo M. Peñalver, Exactions Creep, December 2013

449. Lee Anne Fennell, Forcings, December 2013

450. Jose Antonio Cheibub, Zachary Elkins, and Tom Ginsburg, Beyond Presidentialism and Parliamentarism, December 2013

451. Nicholas Stephanopoulos, The South after Shelby County, October 2013

452. Lisa Bernstein, Trade Usage in the Courts: The Flawed Conceptual and Evidentiary Basis of Article 2's Incorporation Strategy, November 2013

453. Tom Ginsburg, Political Constraints on International Courts, December 2013

454. Roger Allan Ford, Patent Invalidity versus Noninfringement, December 2013

455. M. Todd Henderson and William H.J. Hubbard, Do Judges Follow the Law? An Empirical Test of Congressional Control over Judicial Behavior, January 2014

456. Aziz Z. Huq, Does the Logic of Collective Action Explain Federalism Doctrine? January 2014

457. Alison L. LaCroix, The Shadow Powers of Article I, January 2014

458. Eric A. Posner and Alan O. Sykes, Voting Rules in International Organizations, January 2014

459. John Rappaport, Second-Order Regulation of Law Enforcement, April 2015

460. Nuno Garoupa and Tom Ginsburg, Judicial Roles in Nonjudicial Functions, February 2014

461. Aziz Huq, Standing for the Structural Constitution, February 2014

462. Jennifer Nou, Sub-regulating Elections, February 2014

463. Albert W. Alschuler, Terrible Tools for Prosecutors: Notes on Senator Leahy's Proposal to "Fix" Skilling v. United States, February 2014

464. Aziz Z. Huq, Libertarian Separation of Powers, February 2014 
465. Brian Leiter, Preface to the Paperback Edition of Why Tolerate Religion? February 2014

466. Jonathan S. Masur and Lisa Larrimore Ouellette, Deference Mistakes, March 2014

467. Eric A. Posner, Martii Koskenniemi on Human Rights: An Empirical Perspective, March 2014

468. Tom Ginsburg and Alberto Simpser, Introduction, chapter 1 of Constitutions in Authoritarian Regimes, April 2014

469. Aziz Z. Huq, Habeas and the Roberts Court, April 2014

470. Aziz Z. Huq, The Function of Article V, April 2014

471. Aziz Z. Huq, Coasean Bargaining over the Structural Constitution, April 2014

472. Tom Ginsburg and James Melton, Does the Constitutional Amendment Rule Matter at All? Amendment Cultures and the Challenges of Measuring Amendment Difficulty, May 2014

473. Eric A. Posner and E. Glen Weyl, Cost-Benefit Analysis of Financial Regulations: A Response to Criticisms, May 2014

474. Paige A. Epstein, Addressing Minority Vote Dilution Through State Voting Rights Acts, February 2014

475. William Baude, Zombie Federalism, April 2014

476. Albert W. Alschuler, Regarding Re's Revisionism: Notes on "The Due Process Exclusionary Rule", May 2014

477. Dawood I. Ahmed and Tom Ginsburg, Constitutional Islamization and Human Rights: The Surprising Origin and Spread of Islamic Supremacy in Constitutions, May 2014

478. David Weisbach, Distributionally-Weighted Cost Benefit Analysis: Welfare Economics Meets Organizational Design, June 2014

479. William H. J. Hubbard, Nuisance Suits, June 2014

480. Saul Levmore and Ariel Porat, Credible Threats, July 2014

481. Brian Leiter, The Case Against Free Speech, June 2014

482. Brian Leiter, Marx, Law, Ideology, Legal Positivism, July 2014

483. John Rappaport, Unbundling Criminal Trial Rights, April 2015

484. Daniel Abebe, Egypt, Ethiopia, and the Nile: The Economics of International Water Law, August 2014

485. Albert W. Alschuler, Limiting Political Contributions after Mccutcheon, Citizens United, and SpeechNow, August 2014

486. Zachary Elkins, Tom Ginsburg, and James Melton, Comments on Law and Versteeg's "The Declining Influence of the United States Constitution," August 2014

487. William H. J. Hubbard, The Discovery Sombrero, and Other Metaphors for Litigation, September 2014

488. Genevieve Lakier, The Invention of Low-Value Speech, September 2014

489. Lee Anne Fennell and Richard H. McAdams, Fairness in Law and Economics: Introduction, October 2014

490. Thomas J. Miles and Adam B. Cox, Does Immigration Enforcement Reduce Crime? Evidence from 'Secure Communities', October 2014

491. Ariel Porat and Omri Yadlin, A Welfarist Perspective on Lies, May 2015

492. Laura M. Weinrib, Civil Liberties outside the Courts, October 2014

493. Nicholas Stephanopoulos and Eric McGhee, Partisan Gerrymandering and the Efficiency Gap, October 2014

494. Nicholas Stephanopoulos, Aligning Campaign Finance Law, October 2014

495. John Bronsteen, Christopher Buccafusco and Jonathan S. Masur, Well-Being and Public Policy, November 2014

496. Lee Anne Fennell, Agglomerama, December 2014 
497. Avital Mentovich, Aziz Z. Huq, and Moran Cerf, The Psychology of Corporate Rights, December 2014

498. Lee Anne Fennell and Richard H. McAdams, The Distributive Deficit in Law and Economics, January 2015

499. Omri Ben-Shahar and Kyle D. Logue, The Perverse Effects of Subsidized Weather Insurance, May 2015

500. Adam M. Samaha and Lior Jacob Strahilevitz, Don't Ask, Must Tell—and Other Combinations, January 2015

501. Eric A. Posner and Cass R. Sunstein, Institutional Flip-Flops, January 2015

502. Albert W. Alschuler, Criminal Corruption: Why Broad Definitions of Bribery Make Things Worse, January 2015

503. Jonathan S. Masur and Eric A. Posner, Toward a Pigovian State, February 2015

504. Richard H. McAdams, Vengeance, Complicity and Criminal Law in Othello, February 2015

505. Richard H. McAdams, Dhammika Dharmapala, and Nuno Garoupa, The Law of Police, February 2015

506. William Baude, Sharing the Necessary and Proper Clause, November 2014

507. William Baude, State Regulation and the Necessary and Proper Clause, December 2014

508. William Baude, Foreword: The Supreme Court's Shadow Docket, January 2015

509. Lee Fennell, Slicing Spontaneity, February 2015

510. Steven Douglas Smith, Michael B. Rappaport, William Baude, and Stephen E. Sachs, The New and Old Originalism: A Discussion, February 2015

511. Alison L. LaCroix, A Man For All Treasons: Crimes By and Against the Tudor State in the Novels of Hilary Mantel, February 2015

512. Alison L. LaCroix, Continuity in Secession: The Case of the Confederate Constitution, February 2015

513. Adam S. Chilton and Eric A. Posner, The Influence of History on States' Compliance with Human Rights Obligations, March 2015

514. Brian Leiter, Reply to Five Critics of Why Tolerate Religion? August 2014

515. Nicholas Stephanopoulos, Teaching Election Law, September 2014

516. Susan Nevelow Mart and Tom Ginsburg, [Dis-]Informing the People's Discretion: Judicial Deference Under the National Security Exemption of the Freedom of Information Act, November 2014

517. Brian Leiter, The Paradoxes of Public Philosophy, November 2014

518. Nicholas Stephanopoulos, Eric McGhee, and Steven Rogers, The Realities of Electoral Reform, January 2015

519. Brian Leiter, Constitutional Law, Moral Judgment, and the Supreme Court as SuperLegislature, January 2015

520. Nicholas Stephanopoulos, Arizona and Anti-Reform, January 2015

521. Lee Anne Fennell, Do Not Cite or Circulate, February 2015

522. Aziz Z. Huq, The Difficulties of Democratic Mercy, March 2015

523. Aziz Z. Huq, Agency Slack and the Design of Criminal Justice Institutions, March 2015

524. Aziz Z. Huq, Judicial Independence and the Rationing of Constitutional Remedies, March 2015

525. Zachary Clopton, Redundant Public-Private Enforcement, March 2015

526. Nicholas Stephanopoulos, Political Powerlessness, March 2015

527. Brian Leiter, Normativity for Naturalists, March 2015

528. Brian Leiter, Legal Realism and Legal Doctrine, April 2015 
529. Adam S. Chilton and Marin K. Levy, Challenging the Randomness Of Panel Assignment in the Federal Courts of Appeals, December 2014

530. Anthony J. Casey and Eric A. Posner, A Framework for Bailout Regulation, February 2015

531. G. Mitu Gulati and Richard A. Posner, The Management of Staff by Federal Court of Appeals Judges, April 2015

532. Daniel Telech and Brian Leiter, Nietzsche and Moral Psychology, April 2015

533. Adam S. Chilton, Using Experiments to Test the Effectiveness of Human Rights Treaties, June 2015

534. Matthew B. Kugler and Lior Jacob Strahilevitz, Surveillance Duration Doesn't Affect Privacy Expectations: An Empirical Test of the Mosaic Theory, July 2015

535. Caroline A. Wong, Sued If You Do, Sued If You Don't: Section 2 of the Voting Rights Act as a Defense to Race-Conscious Districting, April 2015

536. Jonathan S. Masur, The Use and Misuse of Patent Licenses, August 2015

537. Richard H. McAdams, Riley’s Less Obvious Tradeoff: Forgoing Scope-Limited Searches, August 2015

538. Jonathan S. Masur and Eric A. Posner, Unquantified Benefits and Bayesian Cost-Benefit Analysis, August 2015

539. Richard H. McAdams, Empathy and Masculinity in Harper Lee's To Kill a Mockingbird, August 2015 